\title{
Consumption Patterns, Processing and Nutritional Value of Traditional Snack “Mugdugu" Consumed in Rural Areas of Burkina Faso
}

\author{
Fatoumata Hama-Ba ${ }^{1,}$, , Bougouma Boniface ${ }^{1}$, Madina Konaté ${ }^{1}$, Rasmata Dabo ${ }^{1}$, \\ Moussa Moustapha ${ }^{2}$, Brehima Diawara ${ }^{1}$ \\ ${ }^{1}$ Département Technologie Alimentaire, Institut de Recherche en Sciences Appliquées et Technologies (IRSAT), Centre National de \\ Recherche Scientifique et Technique (CNRST), Ouagadougou, Burkina Faso \\ ${ }^{2}$ Institut National de Recherche Agronomique du Niger (INRAN), Niamey, Niger
}

Email address:

hamafatou@yahoo.fr (F. Hama-Ba)

${ }^{*}$ Corresponding author

\section{To cite this article:}

Fatoumata Hama-Ba, Bougouma Boniface, Madina Konaté, Rasmata Dabo, Moussa Moustapha, Brehima Diawara. Consumption Patterns, Processing and Nutritional Value of Traditional Snack "Mugdugu" Consumed in Rural Areas of Burkina Faso. International Journal of Nutrition and Food Sciences. Vol. 6, No. 6, 2017, pp. 237-242. doi: 10.11648/j.ijnfs.20170606.14

Received: May 12, 2017; Accepted: May 22, 2017; Published: November 17, 2017

\begin{abstract}
Traditional African snacks are very little known to the people. The objective of this study is to present the importance of consumption, the process and the nutritional value of a snack traditionally consumed in Burkina Faso. Consumption surveys were conducted among 250 adults in rural and urban areas Lebda and Kaya in the north center area of Burkina Faso. Production follow ups were carried out at the producers in Kaya and Lebda. Carbohydrates, lipids and proteins, iron and zinc contents were determined. Mugdugu is well known to the populations, 97\% know it and have used it at least once. Nearly $46 \%$ and $20 \%$ of respondents in Lebda and Kaya consumed it at least once a week. The market is the main place of supply in the two localities. Mugudugu is consumed by all age, 1 year to more than 45 years. Mugdugu is based on millet (Pennissetum glaucum) and peanut (Arachis hypogea). The process is based on two essentials steps: roasting and grinding. The average contents of carbohydrates, lipids and proteins are respectively $61.78 \%, 21.67 \%$ and $14.45 \%$. Those of iron and zinc are $11.97 \%$ and $3.97 \%$ respectively. The association of cereal and legume make Mugudugu an interesting snack of good nutritional value that must attract the attention of nutrition actors.
\end{abstract}

Keywords: Snack, Tradition, Processing, Legumes, Rural

\section{Introduction}

Traditional African snacks are very little known to the people. In developing countries, urban and rural markets are flooded with modern snacks such as biscuits, cakes and pastries. Snacks or between-meals snacks are important in people's diet. Snacking is extremely common among children and plays a vital role in meeting food needs [1]. According to many studies, snacks cover 21 to $25 \%$ of children's daily energy needs [2, 3]. In developing countries where basic dishes are monotonous and of poor nutritional value $[4,5]$, snacks are an important source of nutrients. Traditional snacks consumed in West Africa such as masa have low nutritional values [6]. Most snacks have high energy value with low nutritional value, high sugar and salt contents $[7,8$, $9,10,11,12,13]$. The impact of snacking on people's health in many countries has been the subject of many studies. Developed countries such as France, Switzerland, England, Sweden, have introduced more options in snacking to improve the health of the people $[14,15]$.

A snack rich in essential nutrients based on pre-existing population preferences could contribute to improving the nutritional value of people's diets where protein and energy deficiencies are prevalent.

A good knowledge of the nutritional value of traditional snacks is an advantage to improving the nutritional condition of rural populations in developing countries. 
"Mugudugu" or "djimita" in local languages of Burkina Faso is a traditionally consumed snack. It is based on millet and groundnut. This study presents the level of consumption in urban and rural areas, production processes and the nutritional value of this local snack.

\section{Material and Methods}

\subsection{Consumer Survey}

The study was conducted in the Central North region of Burkina Faso. The places concerned are Kaya and Lebda. The city of Kaya is the main city of the region. Lebda is a village located at $20 \mathrm{~km}$ from Kaya and belongs to the rural town of Pissila.

A total of 250 adults were surveyed on the consumption of Mugudugu. 135 respondents in Kaya and 115 respondents in Lebda were targeted. The adults were chosen randomly. Table 1 shows the distribution of respondents in the various study locations.

Each respondent was administered a questionnaire comprising the identity of the respondent, the level of knowledge, the source of supply, the frequency of consumption of Mugudugu.

\subsection{Processor Survey}

The processor survey consisted of figuring out the different processing steps of mugudugu, the raw materials and the ingredients used. This survey was conducted in Kaya and in Lebda with the mugudugu producers. 30 processors in Kaya and 16 in Lebda were investigated. The production units are small units on a family scale.

\subsection{Sampling and Biochemical Analysis}

In each location 3 samples from different units were collected and sent to the laboratory for biochemical testing. Biochemical tests were carried out on moisture, macronutrient contents according to AOAC methods [16] and iron and zinc mineral contents.

The water content was determined by differential weighing after putting the sample in an oven at $105^{\circ} \mathrm{C}$. The total proteins are determined from the Kjeldah method. The identification of the fat content is made according to the Soxhlet extraction method using hexane as solvent. The ashes were determined by incineration in a muffle furnace at $550^{\circ} \mathrm{C}$.

The total carbohydrate content was determined by the differential method [17].

The theoretical energy value was calculated from analytical values of total protein, fat and carbohydrates according to the Merrill and Watt method adopted by the FAO in 1970.

\subsection{Statistical Analyses}

Data from the consumer survey were processed on Excel. Data from biochemical testing were introduced on Excel, the mean and standard deviation were determined.

\section{Results}

\subsection{Consumer Survey}

\subsubsection{Characteristics of Respondents}

Table 1 shows the characteristics of respondents. The survey interviewed $47 \%$ of women and $53 \%$ of men overall. Nearly $33 \%$ and $26 \%$ of respondents are between the ages of $18-25$ and $26-35.18 \%$ of respondents are between 36 and 45 years old and $23 \%$ are over 45 years old.

Educational attainment is low, $56 \%$ of respondents are illiterate, $24 \%$ are literate (local languages), $7 \%$ are primary, $11 \%$ are secondary and $2 \%$ are higher.

About all respondents, 97\% knew mugudugu and had consumed it at least once. In Kaya 95\% of respondents say they know mugudugu and $99 \%$ in Lebda. Overall, $81 \%$ of respondents believe that mugudugu is well known in the community, while $15 \%$ believe it is fairly well known. Only $3 \%$ say it is not known at all in the area.

Table 1. Characteristics of respondents of Kaya and Lebda.

\begin{tabular}{ll}
\hline Characteristics & respondents\% \\
\hline Men & 53 \\
Women & 47 \\
Age & \\
18-25 years & 33 \\
26-35 years & 26 \\
36-45 years & 23 \\
More than 45 years & 18 \\
Knowlege level & \\
Very well & 44 \\
Well & 37 \\
Fairly well & 15 \\
Never & 4 \\
\hline
\end{tabular}

\subsubsection{Consumption Frequency}

Figure 1 shows the frequency of Mugudugu consumption for all areas of the consumer survey. In Lebda, nearly $16 \%$ consumed Mugudugu at least once a day, $46 \%$ of respondents consumed it during the week. While in Kaya 27\% consumed at least once in the month and $38 \%$ consumed at least once in a year.

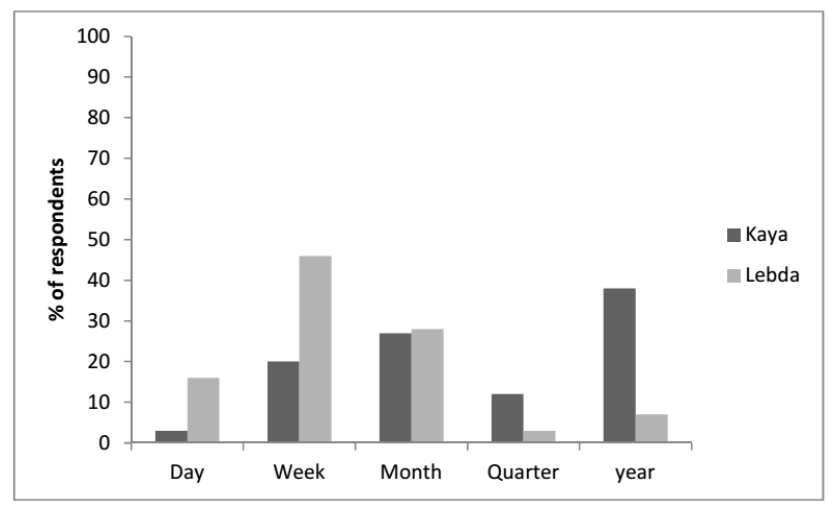

Figure 1. Frequency of Mugudugu consumption. 


\subsubsection{Supply Places}

The market is the main place of sale in Kaya and Lebda respectively $78 \%$ and $97 \%$. Mugudugu is also found with street vendors, in shops and at women's homes. In Kaya, 34\% and $39 \%$ of the respondents are supplied respectively from street vendors and women's producers' homes. In Lebda, boutiques are a source of supply for $15 \%$ of respondents.

Table 2. Supply source of Mugudugu according to the respondents (\%).

\begin{tabular}{lll}
\hline Supply place & Kaya & Lebda \\
\hline Market & 78 & 97 \\
Street vendors & 34 & 15 \\
\hline
\end{tabular}

\begin{tabular}{lll}
\hline Supply place & Kaya & Lebda \\
\hline Alimentations & 0 & 0 \\
Shops & 9 & 15 \\
Home of producers & 39 & 11 \\
\hline
\end{tabular}

\subsection{Processing}

The raw materials used by all female producers are millet and groundnut. The main ingredients are sugar, salt, oil and spices. The spices mentioned are pepper and ginger. The use of spices varies from one production to another with the same producer (Figure 2).
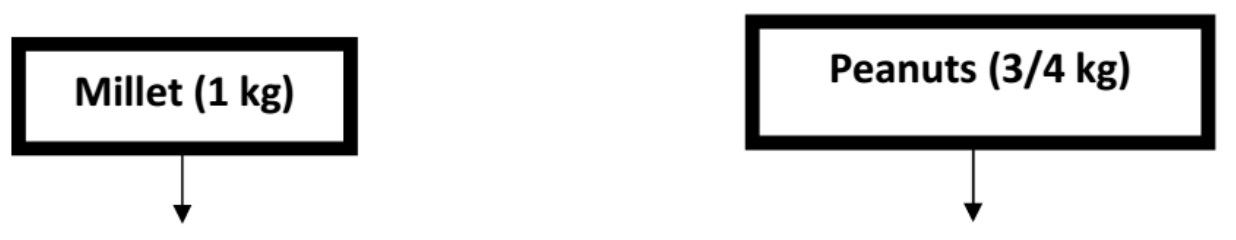

Washing

Sorting

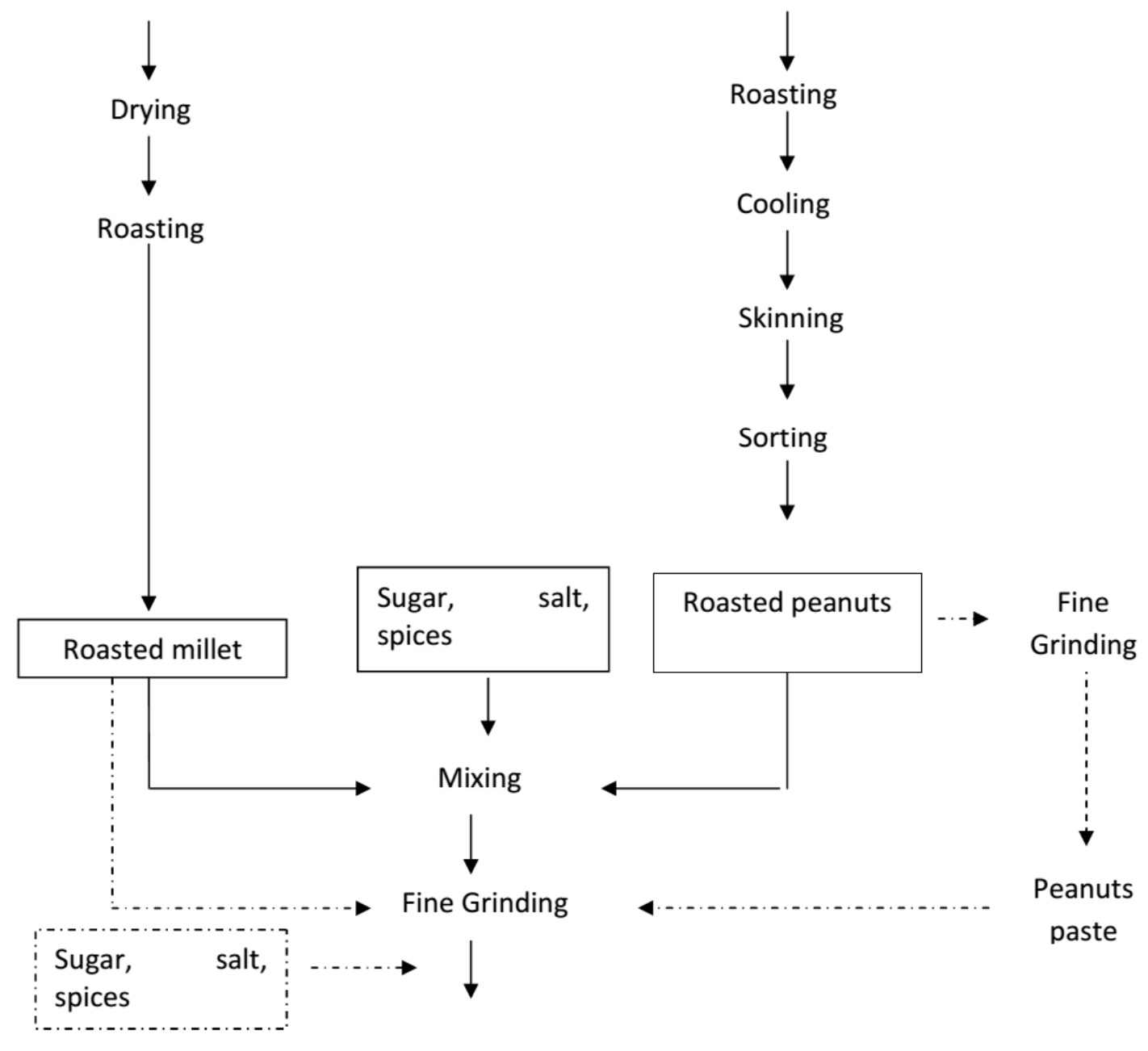

Mugudugu

Figure 2. Diagram of production of Mugudugu. 


\subsubsection{Production Steps}

The production of Mugudugu is done in three stages (Table 3 ). The first stage involves the processing of millet, the second stage is the processing of groundnuts, and the third stage involves mixing millet and groundnuts. The various operations of millet processing are cleaning, washing, drying, roasting and grinding. Millet was roasted by all producers while 14/30 producers in Kaya and 16/16 in Lebda ground the roasted millet. The other producers ground the millet with the mixture of groundnuts and the ingredients.

The main stages of groundnut processing are roasting and grinding. Groundnuts are roasted and ground by all producers before shredding. In Kaya 5 producers grind groundnuts in groundnut paste.

The mixture is the last stage of processing of Mugudugu. In Kaya and Lebda respectively $25 / 30$ and 16/16 producers blend millet flour, roasted groundnuts and ingredients. The mixture is finely ground to give Mugudugu.

Table 3. Frequency of use of operations during transformation of Mugudugu.

\begin{tabular}{llll}
\hline Steps & Operations & $\begin{array}{l}\text { Kaya }(30 \\
\text { producers })\end{array}$ & $\begin{array}{l}\text { Lebda (16 } \\
\text { producers) }\end{array}$ \\
\hline \multirow{4}{*}{ Millet } & Cleaning & 1 & 16 \\
& Washing & 14 & 0 \\
& Draining & 1 & 0 \\
& Drying & 6 & 0 \\
& Roasting & 30 & 16 \\
& Grinding & 15 & 16 \\
& Sorting/Cleaning & 5 & 16 \\
& Washing & 0 & 0 \\
& Draining & 0 & 0 \\
& Drying & 0 & 0 \\
& Roasting & 30 & 16 \\
& Skinning & 4 & 16 \\
Mixing & Grinding & 5 & 0 \\
& Mixing & 30 & 16 \\
& Grinding & 30 & 16 \\
\hline
\end{tabular}

\subsubsection{Main Customers}

According to the response given by the processors, Mugudugu is consumed by both women and men (Table 4). In Lebda men consume more than women. It is consumed by all ages in Kaya and Lebda. Children are the main consumers in both areas, $98 \%$ and $83 \%$ respectively in Kaya and Lebda.

Table 4. Main customers of Mugudugu.

\begin{tabular}{llll}
\hline & & Kaya (\%) & Lebda (\%) \\
\hline \multirow{2}{*}{ Sex } & Men & 90 & 83 \\
& Women & 90 & 72 \\
\multirow{2}{*}{ Age } & Children (1-16 years) & 98 & 83 \\
& Young (17-45 years) & 84 & 67 \\
& More than 45 years & 74 & 67 \\
\hline
\end{tabular}

\subsection{Physico-chemical Characteristics}

Table 5 shows the nutritional composition of Mugudugu. Mugudugu is a low moisture product, $4.09 \%$. It is highly energetic, $499.95 \mathrm{Kcal} / 100 \mathrm{~g}$ of dry product. The carbohydrate content are $61.78 \mathrm{~g} / 100 \mathrm{~g}$ and the fat content are $21.67 \mathrm{~g} / 100 \mathrm{~g}$. The protein content are $14.45 \mathrm{~g} / 100 \mathrm{~g}$ of dry product. While the iron and zinc mineral contents are $11.97 \mathrm{mg} / 100 \mathrm{~g}$ and $3.97 \mathrm{mg} / 100 \mathrm{~g}$, respectively.

Table 5. biochemical composition of Mugudugu (100 g of dry matter).

\begin{tabular}{ll}
\hline Parameters (unity) & Contents \\
\hline Humidity\% & $4,09 \pm 0,71$ \\
Protein $\mathrm{g} / 100 \mathrm{~g}$ & $14,45 \pm 0,03$ \\
Fats g/100 g & $21,67 \pm 2,24$ \\
Carbohydrates g/100 g & $61,78 \pm 0,1$ \\
Iron $\mathrm{mg} / 100 \mathrm{~g}$ & $11,97 \pm 0,05$ \\
Zinc $\mathrm{mg} / 100 \mathrm{~g}$ & $3,97 \pm 0,03$ \\
Energy $(\mathrm{Kcal} / 100 \mathrm{~g})$ & $499,95 \pm 0,07$ \\
\hline
\end{tabular}

\section{Discussion}

Mugudugu is a snack well known to people in Kaya and Lebda. Only $4 \%$ of respondents do not know it. It is a snack regularly consumed by all age groups, although children are the biggest consumers in both areas. Consumption is more regular in Lebda village where nearly $46 \%$ of respondents consume it once in a week. In Lebda the number of male consumers is higher than that of women. According to the outcomes of previous studies conducted in other countries such as China, Australia, the United Arab Emirates, the United States, the snacking trend is high among women [18, 19]. However, this could be explained by the low spending power of rural women in Burkina Faso.

The market is the main place of supply. The sale of mugudugu is done at the homes of the producers and also by street vendors.

Mugudugu is a high energy dry product, $499.5 \mathrm{kcal} / 100 \mathrm{~g}$. The low moisture content makes Mugudugu a barely perishable product. Indeed, roasting is an essential operation during the production of Mugudugu. Roasting has the advantage of destroying undesirable microorganisms and inactivating enzymes. It allows a better preservation of the product. Carbohydrates and lipids account for nearly $3 / 4$ of the components. Most snacks are based on cereals, they are mainly rich in carbohydrates and fat [20; 21, 22 23]. In America, nearly $27 \%$ of children's daily energy comes from snacks. The snacks have an impact on public health (24). The addition of sugar in mugudugu requires special attention for its consumption. A study conducted in England showed a correlation between snacking and subcutaneous skinfold thickness in obese people [11].

The protein content of Mugudugu is high, $14.45 \mathrm{~g} / 100 \mathrm{~g}$ of dry product, compared to cereal snacks usually consumed such as biscuits and masa. Some authors [25] reported protein levels of $6.8 \%$ in corn biscuits. Rice snacks in Thailand have protein levels of 2.44-11.06 g/100 g [26]. The combination of millet and groundnuts makes Mugudugu an interesting nutritional product. The cereal and legume combination has long been advocated as an important source of energy and protein for young children [27]. Several studies have shown an improvement in protein levels by combining legumes with carbohydrate-rich foods. The addition of bean 
and groundnut seeds to rice and millet improved the protein content of the products [28]. In addition to quantity, the combination of cereals and legumes improves the quality of amino acids [29]. A smart combination of cereals and legumes provides a food with high nutritional value.

However, the nutritional quality of Mugudugu, although interesting, could be influenced by roasting. According to many studies, roasting could lead to decomposition of proteins or cross-reactions of essential amino acids such as lysine, arginine or the Maillard reaction. Hence the need to control the time / temperature couple for a good nutritional quality of Mugudugu.

The iron and zinc content of Mugudugu is higher for the children 1 year to 3 years according to the FAO/WHO recommandations [30] Many contaminations of iron has been observed during traditional processing [31, 32].

\section{Conclusion}

Mugudugu is a traditional snack which is popular with consumers in Kaya and Lebda in Burkina Faso. Since children are the main customers, special attention must be paid to the nutritional and hygienic quality of the product. A control of the time/temperature couple and the use of low-fat groundnut varieties could improve the nutritional quality of the product. Mugudugu could also be used as a fortification for children in rural areas.

\section{References}

[1] Zizza Claire, Siega-Riz Anna Maria, Popkin Barry. Significant increase in young adults'snaking between 1977-1978 and 1994-1996 represent a cause for concern. Preventive Medicine, 2001, volume 32, Issue 4, page 303-310.

[2] Skinner JD, Ziegler P, Pac S, Devaney B. Meal and snack patterns of infants and toddlers. J Am Diet Assoc. 2004, 104 (1 Suppl 1): 65-70.

[3] Macdiarmid J, Loe J, Craig LC, Masson LF, Holmes B, McNeill G. Meal and snacking patterns of school-aged children in Scotland. Eur J Clin Nutr. 2009 Nov; 63(11):1297304.

[4] Gibson RS, Hotz C. Dietary diversification / modification strategies to enhance micronutrient content and bioavailability of diets in developing countries. Br J Nutr; 2001, 85 Suppl 2: S $159-66$.

[5] Icard-Vernière Christèle, Olive Fanny, Picq Christian, Mouquet-Rivier Claire. Contribution of Leafy Vegetable Sauces to Dietary Iron, Zinc, Vitamin A and Energy Requirements in children and their mothers in Burkina Faso Plant Foods Hum Nutr. 2015. 70:63-70 DOI 10.1007/s11130014-0462-5

[6] Ayo J. A, Onuoha G, Agu H, Ayo V. A, Avu E. O, Sosanya M, and Adeosun F. Effect of added beneseed paste on the quality of millet-based masa. African Journal of Food Science and Technology 2012, Vol. 3(10) pp. 236-243. ISSN: 2141-5455.

[7] Oogarah - Pratap B., Heerah - Booluck B. J. "Children's consumption of snacks at school in Mauritius", Nutrition \&
Food Science, 2005, Vol. 35 Iss: 1, pp. 15-19. http://dx.doi.org/10.1108/00346650510579117

[8] Sebastian RS, Cleveland LE, Goldman JD, J. Adolesc Effect of snacking frequency on adolescents' dietary intakes and meeting national recommendations. Health. 2008; 42 (5):50311. http://dx.doi.org/10.1016/j.jadohealth.2007.10.002

[9] Lipoeto NI, Geok Lin K, Angeles-Agdeppa I. Food consumption patterns and nutrition transition in South-East Asia. Public Health Nutr 2013; 16:1637-43. 13.

[10] Duffey KJ, Pereira RA, Popkin BM. Prevalence and energy intake from snacking in Brazil: analysis of the first nationwide individual survey. Eur J Clin Nutr 2013; 67:868-74.

[11] O' Connor L, Brage S, Griffin SJ, Wareham NJ, Forouhi NG. The crosssectional association between snacking behaviour and measures of adiposity: the Fenland Study, UK. Br J Nutr; 2015;.114:1286-93.

[12] Adegunwa, M. O., Ganiyu, A. A., Bakare, H. A. and Adebowale, A. A. Quality evaluation of composite milletwheat Chinchin. Agriculture and Biology Journal of North America, 2014, 5(1): 33-39.

[13] Bellisle F. Meals and snacking, diet quality and energy balance. Physiol Behav; 2014, 134:38-43.

[14] Ancellin R, Baelde D, Barthélémy L, Bellisle F, Berta J-L, Boute D, Castetbon K, Chauliac M, Duchéne C, Dumas C. Ministry of Health and Welfare. Dietary guidelines for adults in Greece. Arch Hell Med; 1999, 16:516-24.

[15] Ancellin R, Baelde D, Barthelemy L, Bellisle F, Berta J-L, Boute D, Castetbon K, Chauliac M, Duchene C. Le guide alimentaire pour tous. 2011. Available from: http://www. inpes.sante.fr/CFESBases/catalogue/pdf/581.pdf. 83.

[16] Association of Official Analytical Chemists. Official Methods of Analysis of AOAC International. 18th ed. Arlington, VA: AOAC International; 2005.

[17] Egan H, Kirk RS, Sawyer R. Pearson's Chemical Analyses of Food (8th edition). Churchill. Livingstone: London-UK; 1981, $591 \mathrm{p}$.

[18] Popkin BM, Duffey KJ. Does hunger and satiet y drive eating any more? Increasing eating occasions and decreasing time between eating occasions in the United States. Am J Clin Nutr; 2010, 91:1342-7.

[19] Kant AK, Graubard BI. 40-Year trends in meal and snack eating behaviors of American adults. J Acad Nutr Diet; 2015, 115:50-63.

[20] Leverton, R. M. The paradox of teen-age nutrition. J. Am. Diet. Assoc. 1968, 53: 13-18

[21] Sparks, G. Teen-age snacking habits: A challenge for nutrition education. J. Am. Diet Assoc. 1975, 66: 371-375.

[22] Mc Coy, H., S. Moak, M. A. Kenny, A. Kirby, L. Chopin, W. Billon, A. Clark, G. Disney F. G. Ercanli, E. Glover, M. Korslund, H. Lewis, S. J. Kitchey, P. Schilling, S. Shoffner, and T. Wakefield. Snacking patterns and nutrient density of snacks consumed by southern girls. J. Nutr. Ed. 1986, 18: 6166.

[23] Tettweiler, P. 1991. Snack foods worldwide. Food Technol. 45: $58-62$. 
[24] Piernas C, Popkin BM. Trends in snacking among U.S. children. Health Aff (Millwood) 2010; 29:398-404.

[25] Adeyeye, Samuel A., Akingbala, John O. 2014. Evaluation of Nutritional and Sensory Properties of Cookies Produced from Sweet Potato- Maize Flour Blends. Researcher 2014; 6(9). http://www.sciencepub.net/researcher

[26] Plernchai Tangkanakul, Patcharee Tungtrakul, and Wanpen Mesomya. Nutrient Contents of Commercial Snack Food Products Kasetsart J. Nat. Sci. 1999, 33: 270-276.

[27] Mensah P, Tunkins A. Household level technologies to improve the availability and preparation of adequate protein and safe complementary foods In; Food and Nutrition Bulletin, 2003, 24:104-125.

[28] Nkama I, Malleshi NG Production and nutritional quality of traditional masa from mixture of rice, pearl millet, cowpea and groundnut. Food Nutrition Bulletin, 1998. 19: 336-373.

[29] Solomon Mariam. Nutritive value of three potential complementary foods based on cereal and legumes. African
Journal of Food and Nutritional Sciences: 2005; Volume 5 $\mathrm{N}^{\circ} 2$.

[30] Food and Agriculture Organization/World Health Organization (FAO/WHO). 2002. Human vitamin and mineral requirements. Report of a joint $\mathrm{FAO} / \mathrm{WHO}$ expert consultation. FAO/WHO.

[31] Fatoumata Hama, Christèle Icard-Vernière, Jean-Pierre Guyot, Christian Picq, Diawara, Brehima., Mouquet-Rivier Claire.). Evolution of the micro- and macronutrient composition of pearl millet (Pennisetum glaucum) and whitesorghum (Sorghum bicolor) during in field versus laboratory decortications. Journal of Cereal Science, 2011, 54, 425433.60-1668.

[32] Fatoumata Hama, Christèle Icard-Vernière, Jean-Pierre Guyot, Isabelle Rochette, Bréhima Diawara, Claire Mouquet-Rivier. Potential of non-GMO biofortified pearl millet (Pennisetum glaucum) for increasing iron and zinc content and their estimated bioavailability during abrasive decortications. International Journal of Food Science and Technology, 2012, 47, 1660-1668. 